\title{
Assessment of flatulence causing agents in Chickpea (Cicer arietinum L.) and their possible removal
}

\author{
Talat MAHMOOD ${ }^{1}$, Tabasum HAMEED ${ }^{2}$, Sabahat HASNAIN ${ }^{3}$, Sartaj ALI ${ }^{4}$, Abdul QAYYUM ${ }^{1 *}$, \\ Ayaz MEHMOOD ${ }^{1}$, Muhammad LIAQUAT ${ }^{1}$, Sami Ullah KHAN ${ }^{1}$, Muhammad SAEED ${ }^{1}$, Ayub KHAN ${ }^{1}$
}

\begin{abstract}
Flatulence and fullness of stomach is one of the most common problem associated with chickpea primary due to presence of some oligosaccharides and phenols. In this investigation Desi and Kabuli varieties were compared for these oligosaccharides and phenolic compounds. Furthermore, the effect of different processing and cooking methods such as soaking, cooking and germination in the reduction of these antiphysiological factors were are also studies. Maximum tannic acid $(0.90 \pm 0.20 \%)$ was observed in Parbat and C-44 while minimum $(0.60 \pm 0.04 \%)$ in Karak-2. Stachyose contents ranged between $1.10 \pm 0.05$ (Karak-3) to $1.42 \pm 0.02 \%$ (Parbat) while raffinose was $0.63 \pm 0.05$ (Karak-3) to $0.81 \pm 0.02 \%$ (Dasht). The highest tannic acid content was reduced up to $50 \%$ in C-44 by cooking of 72 hours germinated seeds. Stachyose and raffinose contents were completely removed after 72 hours germination. Present studies revealed that cooking after germination is the most effective method to reduce the anti-nutritional factors of chickpea. Individually, soaking and cooking also contributed to the loss of the same factors but to a lesser extent.
\end{abstract}

Keywords: Chickpea; anti-nutritional factors; tannic acid; stachyose; raffinose.

Practical Application: Health benefits of Chickpea.

\section{Introduction}

A significant part of the world population relies on legumes as staple food particularly in combination with cereals. Chickpea (Cicer arietinum $\mathrm{L}$.) are one of the oldest and most widely consumed legumes often advocated in human diet because of their beneficial nutritional effects and a low cost protein source (Brummer et al., 2015). Although, the protein content of legume grains is relatively high but its protein quality is low (Ahmed et al., 2006). This has been attributed to the deficiency of sulpher containing amino acids and the presence of anti-nutritional factors such as tannic acid, polyphenols and flatulence causing oligosaccharides like stachyose and raffinose (El-Adawy, 2002).

Chickpea has the capacity to synthesize certain biologically active substances commonly considered as anti-nutritional factors that affect the animal and human nutrition (Esenwah \& Ikenebomeh, 2008). Tannic acid present in chickpea inhibits the activities of trypsin, chymotrypsin, amylase and lipase (Tahir et al., 2012). Tannin also interferes with dietary iron absorption (Prasad \& Singh, 2015). More than $10 \mathrm{mg}$ tannic acid per $\mathrm{kg}(10 \mathrm{ppm})$ of diet induces anemia by reducing iron absorption and reduces the haemoglobin concentration and serum iron concentration (Afsana et al., 2004). Other factors like flatulence causing oligosaccharides (raffinose and stachyose) are responsible for feeling of fullness after eating, uncomfortable feeling and with or without visible abdominal enlargement (Singh \& Kayastha, 2013).

Processing methodologies like soaking, germination and heat treatment are used to reduce the anti-nutritional factors (Mubarak, 2005). Soaking and germination can activate native enzymes that degrade inositol-6-phosphate to its lower forms. Soaking of legume seeds, such as peas, groundnuts and pigeon peas, has been reported to reduce tannic acid by about $20 \%$ (Masud et al., 2007), whereas germination of legume seeds grains reduced their tannin up to 50\% (Ramakrishna et al., 2006). Domestic cooking or industrialized processing has generally been reported to cause more moderate losses of anti-nutritional factors. Boiling or pressure-cooking of mung bean or black gram resulted in a 5-15\% tannins loss (Osman, 2007). Toasting and storage also causing change in the raffinose contents of pluses (Moussou et al., 2017).

Attempts have been made previously to remove or depreciate anti-nutritional factors to permissible level by using different processing techniques, however, studies in context to select the varieties without any treatment and to find suitable methods with reference to different time periods for reduction of anti-nutritional factors in chickpea is still to explore. Furthermore, a better 
understanding of different traditional processing methods may lead to wider use of the legume for food industry.

\section{Materials and methods}

\subsection{Sampling and sample preparation}

Samples of three Desi chickpea varieties (Dasht, Parbat and C-44 having dark brown seed coat) and three Kabuli varieties (Karak1, Karak2 and Karak3 salmon white seed color) were collected from Pulses and Oil Seed Programs, National Agricultural Research Center Islamabad, Pakistan. Collected samples were stored at $4{ }^{\circ} \mathrm{C} \pm 0.5$ in polyethylene bags of porosity $0.02 \mathrm{~mm}$. Before the analysis, sub sampling was performed and 200 gram of each chickpea varieties were ground and analyzed for given parameters. 200-gram whole chickpea seeds of each variety were ground by using Cyclotec Mill (Cyclotec 1093, Tecator Sweden) according to the American Association of Cereal Chemist (2000) method No 64-70A. Flour was analyzed for tannin acid, raffinose and stachyose of each chickpea variety without any treatment. i.e. control.

\subsection{Application of processing methodologies}

Soaking of chickpea

Chickpea seeds were soaked for 6, 12 and 24 hours (seeds to water ratio of $1: 5 \mathrm{w} / \mathrm{v}$ ) at room temperature as described by Hameed et al. (1999). The samples were dried over-night at $50^{\circ} \mathrm{C}$ in hot- air oven, were ground in Cyclotec Mill and analyzed for tannic acid, raffinose and stachyose.

\section{Germination of chickpea}

Overnight soaked chickpea seeds (zero hours germinated) were transferred to sterile petri dishes lined with wet filter paper and germinated for 24,48 and 72 hours at $28^{\circ} \mathrm{C}$ with frequent watering as described by Lukow \& Bushak (1984). Samples were dried overnight at $50^{\circ} \mathrm{C}$ in hot air oven (BST/HAO-1122, Bionics Scientific Technologies (P)LTD, ground in Cyclotec Mill and analyzed for aforesaid anti-nutritional factors.

\section{Cooking of chickpea}

Chickpea seeds from each treatment were cooked (seeds to water ratio of $1: 5 \mathrm{w} / \mathrm{v}$ ) on a hot plate until they become soft as described by Khokhar \& Chauhan (1986). Samples were dried over-night at $50^{\circ} \mathrm{C}$ in hot air oven, ground in Cyclotec Mill and analyzed for above mentioned anti-nutritional factors.

\subsection{Chemical analysis}

Tannic acid

Tannic acid contents of the samples were determined by spectrophotometer (Spectronic 21, Million Roy Company) at $760 \mathrm{~nm}$ using Folin-Denis reagent (Sigma Alrich, USA) according to the Association of Official Analytical Chemists (2005) method No. 952.03. A $0.5 \mathrm{~g}$ of ground sample was taken in $100 \mathrm{ml}$ conical flask, $50 \mathrm{ml}$ water was added and boiled for one hour. Sample was filtered through cotton wool in $50 \mathrm{ml}$ volumetric flask and made the volume when cool. Aliquots solution 1-3 ml was pipette into $100 \mathrm{ml}$ volumetric flask containing $75 \mathrm{ml}$ distilled water. $5 \mathrm{ml}$ Folin Denis reagent and $10 \mathrm{ml}$ saturated Sodium Carbonate ( $35 \mathrm{~g}$ in $100 \mathrm{ml}$ distilled water) was added and diluted the volume up to $100 \mathrm{ml}$ with water. Standard curve was made by taking Tannic Acid Sigma-Aldrich) concentration in $\mathrm{ml}(1 \mathrm{ml}=0.1 \mathrm{mg}$ tannic acid $)$ on $\mathrm{X}$-axis and optical density (O. D) on Y-axis. Tannic acid was calculated by using following Formula 1.

Tannic acid $(\%)=[$ mg tannic acid from graph $\times$ Extract volume $(\mathrm{ml})] /{ }_{(1)}$
$[10 \times$ Aliquot $(\mathrm{ml}) \times$ Sample weight $(\mathrm{g})]$

\section{Raffinose and Stachyose}

Separation of flatulence causing oligosaccharides (Raffinose and Stachyose) accomplished on whatman No.1 chromatographic paper by descending chromatography using the solvent butanol-pyridine-water (5:1:4 v/v, Merck). The chromatogram is run for about 72 hours. The paper was removed, dried with hot air and marginal strips are cutoff and sprayed with a solution of Ammonical Silver Nitrate (Sigma-Aldrich). The strips were heated in an oven at $110^{\circ} \mathrm{C}$, until the dark spots indicating the position of the sugars appear. With the aid of lines on the central un-spread portion of the chromatogram and using the developed spots on the marginal strips as indicator, sections of paper corresponding to raffinose and stachyose positions was cut from the central positions (Singh et al., 1991). The sugars from the strips were eluted with water and their concentrations estimated colorimetrically on spectrophotometer (Dubois et al., 1956).

\subsection{Statistical analysis}

Data obtained were analyzed statistically by using two factors factorial by Complete Randomized Design (CRD) according to methods of Steel et al. (1996) by using M-STATC computerized software.

\section{Results and discussion}

\subsection{Effect of processing on the Tannic acid contents}

Tannic acid content in six chickpea varieties after different treatments, i.e. control, soaking, germination, cooking and their different combinations, is shown in Table 1.

Chickpea varieties were significantly different $(\mathrm{P}<0.05)$ from one another. Tannic acid ranged between $0.6 \pm 0.04$ to $0.9 \pm 0.02 \%$. Generally, Desi varieties had more tannic acid as compared to Kubali. The highest tannic acid $(0.9 \pm 0.02 \%)$ was found in Parbat and C-44 while $0.6 \pm 0.04 \%$ in Karak1. Soaking of chickpea in the plain water for 6,12 and 24 hours reduce the tannic acid proportionally throughout the different soaking intervals. The highest tannic acid loss (25\%) was observed in Dasht, after 24 hours of soaking. Tannic acid was also determined after 24, 48 and 72 hours germination and it was observed that maximum loss (38.8\%) occurred after 72 hours of germination. Similarly, when cooking applied, it reduced 21.0 to $33 \%$ tannic acid in Karak1 and Parbat, respectively. In combinations of soaking with cooking, loss of tannic acid extended up to $42.0 \%$ in C- 44 
Table 1. Effect of different processing methods on the tannic acid (\%) contents of chickpea.

\begin{tabular}{|c|c|c|c|c|c|c|}
\hline & \multicolumn{3}{|c|}{ Desi (dark brown seed coat) } & \multicolumn{3}{|c|}{ Kabuli (salmon white seed color) } \\
\hline & Parbat & Dasht & C-44 & Karak-1 & Karak-2 & Karak-3 \\
\hline \multicolumn{7}{|l|}{ Soaking } \\
\hline Raw / Control & $0.90 \mathrm{a} \pm 0.02$ & $0.75 \mathrm{~cd} \pm 0.01$ & $0.90 \mathrm{a} \pm 0.02$ & $0.65 \mathrm{e} \pm 0.05$ & $0.60 \mathrm{fg} \pm 0.04$ & $0.70 \mathrm{de} \pm 0.01$ \\
\hline 12 hrs. Soaking & $\begin{array}{c}0.75 \mathrm{~cd} \pm 0.01 \\
(16)\end{array}$ & $\begin{array}{c}0.61 \text { ef } \pm 0.05 \\
\text { (19) }\end{array}$ & $\begin{array}{l}0.74 \mathrm{~d} \pm 0.07 \\
\quad(17)\end{array}$ & $\begin{array}{c}0.58 \mathrm{~g} \pm 0.09 \\
(10)\end{array}$ & $\begin{array}{c}0.50 \mathrm{~h} \pm 0.04 \\
\quad(16)\end{array}$ & $\begin{array}{c}0.60 \mathrm{fg} \pm 0.02 \\
(16)\end{array}$ \\
\hline \multicolumn{7}{|l|}{ Soaking \& Cooking } \\
\hline Raw / control & $0.90 \mathrm{a} \pm 0.02$ & $0.75 \mathrm{~b} \pm 0.01$ & $0.90 \mathrm{a} \pm 0.09$ & $0.65 \mathrm{bcd} \pm 0.05$ & $0.60 \mathrm{def} \pm 0.04$ & $0.70 \mathrm{bc} \pm 0.01$ \\
\hline 8 hrs. Soaking / Cooking & $\begin{array}{c}0.57 \text { efg } \pm 0.04 \\
(36)\end{array}$ & $\begin{array}{c}0.51 g-j \pm 0.07 \\
(32)\end{array}$ & $\begin{array}{c}0.60 \operatorname{def} \pm 0.01 \\
\text { (33) }\end{array}$ & $\begin{array}{c}0.45 \mathrm{jkm} \pm 0.06 \\
(32)\end{array}$ & $\begin{array}{c}0.41 \mathrm{klm} \pm 0.10 \\
(31)\end{array}$ & $\begin{array}{c}0.48 \text { hij } \pm 0.10 \\
\quad(31)\end{array}$ \\
\hline 12 hrs. Soaking / Cooking & $\begin{array}{c}0.5 \text { lghi } \pm 0.05 \\
(43)\end{array}$ & $\begin{array}{c}0.49 \text { gjk } \pm 0.08 \\
(35)\end{array}$ & $\begin{array}{c}0.55 \text { fgh } \pm 0.01 \\
(36)\end{array}$ & $0.42 \mathrm{klm} \pm 0.17$ & $\begin{array}{c}0.40 \operatorname{lm} \pm 0.09 \\
(34)\end{array}$ & $\begin{array}{c}0.44 \mathrm{j}-\mathrm{m} \pm 0.07 \\
(37)\end{array}$ \\
\hline \multicolumn{7}{|l|}{ Germination } \\
\hline Raw/ control & $0.90 \mathrm{a} \pm 020$ & $0.75 b \pm 0.01$ & $0.90 \mathrm{a} \pm 0.09$ & $0.65 c \pm 0.05$ & $0.60 \mathrm{de} \pm 0.04$ & $0.70 \mathrm{bc} \pm 0.01$ \\
\hline 24 hrs. Germination & $\begin{array}{l}0.68 c \pm 0.07 \\
\quad(24)\end{array}$ & $\begin{array}{c}0.60 \mathrm{de} \pm 0.01 \\
(20)\end{array}$ & $\begin{array}{c}0.70 b c \pm 0.18 \\
(22)\end{array}$ & $\begin{array}{c}0.52 \text { fgh } \pm 0.01 \\
(20)\end{array}$ & $\begin{array}{c}0.48 \mathrm{hi} \pm 0.01 \\
(20)\end{array}$ & $\begin{array}{l}0.54 \mathrm{fg} \pm 0.05 \\
(22)\end{array}$ \\
\hline 48 hrs. Germination & $\begin{array}{c}0.65 \mathrm{~cd} \pm 0.06 \\
\quad(28)\end{array}$ & $\begin{array}{l}0.58 \text { ef } \pm 0.01 \\
\quad(23)\end{array}$ & $\begin{array}{c}0.65 \mathrm{~cd} \pm 0.10 \\
\text { (27) }\end{array}$ & $\begin{array}{c}0.50 \mathrm{gh} \pm 0.02 \\
(23)\end{array}$ & $\begin{array}{l}0.45 \mathrm{i} \pm 0.01 \\
\quad(25)\end{array}$ & $\begin{array}{c}0.50 \mathrm{gh} \pm 0.07 \\
(28)\end{array}$ \\
\hline 72 hrs. Germination & $\begin{array}{c}0.60 \mathrm{de} \pm 0.04 \\
(33)\end{array}$ & $\begin{array}{c}0.50 \mathrm{gh} \pm 0.07 \\
(33)\end{array}$ & $\begin{array}{c}0.58 \text { ef } \pm 0.09 \\
(35)\end{array}$ & $\begin{array}{c}0.45 \text { hi } \pm 0.04 \\
(30)\end{array}$ & $\begin{array}{c}0.40 \mathrm{jk} \pm 0.07 \\
(33)\end{array}$ & $\begin{array}{c}0.48 \text { hi } \pm 0.09 \\
\text { (31) }\end{array}$ \\
\hline
\end{tabular}

after 24 hours. Similarly cooking was also used in combination with germination, which enhanced tannic acid reduction up to $50.0 \%$ in the same varieties after 72 hours.

The results obtained are comparable with the findings of (Mubarak, 2005) who reported 0.77 to $0.87 \%$ tannic acid in different varieties of chickpea and reduction in tannic acid content was 6-13\% (8 hours soaking) and 9-20\% (12 hours soaking). In similar kind of studies (El-Adawy, 2002) also reported 8-23 and 14-27\% loss in tannic acid content in three chickpea varieties after 24 and 48 hours of germination while Rao \& Deosthale (1982) observed 59\% loss after 24 hours germination and $64 \%$ after 48 hours, respectively. The results are not much different from the results of (Alajaji \& El-Adawy, 2006) who reported $23.09 \%$ loss of tannic acid in chickpea. However, Rao \& Deosthale (1982) observed 75\% loss on cooking after 24 hours germination. The results are contradictory to (Ramakrishna et al., 2006) who reported 20-29\% loss on cooking after 72 hours germination in chickpea. The difference in results may be due to the variety or different estimation technique. The reduction in tannic acid after cooking may be attributed to two possibilities. Firstly, the tannins were destroyed during the cooking and secondly, tannin formed complexes with other water-soluble substances and leached in cooking water.

\subsection{Effect of processing on the Stachyose contents}

Stachyose contents of six varieties of Desi and Kabuli chickpea are shown in Table 2. Stachyose contents ranged between $1.10 \pm 0.05$ to $1.42 \pm 0.01 \%$ in Karak 1 and Parbat, respectively. Chickpea varieties were significantly different $(\mathrm{P}<0.05)$ from one another. The satchyose content of Desi varieties was higher than that of Kabuli varieties. Table 3 indicates stachyose contents after different treatments, i.e. soaking, germination, cooking and their different combinations. After being soaked, satchyose content of pulses decreased proportionately with the time of soaking and up to $50 \%$ loss was observed after 24 hours soaking in Dasht and Karak1. Cooking treatment also play vital role in stachyose reduction (27 to $31 \%$ ) and when soaking (24 hours) and cooking are combined then loss of stachyose extended to $69 \%$ in Karak1. Germination is most effective method as stachyose content completely removed after 72 hours of germination.

Results are in close agreement with Singh et al. (1991) who has reported 1.06 to $1.85 \%$ stachyose in Dasi chickpea cultivar. These results are also comparable with Myhara et al. (1988) who earlier reported 0.48 to $1.64 \%$ stachyose in various cultivars of black gram. A significant decrease was observed in the levels of stachyose as a result of germination. On germination satchyose contents disappears completely (El-Adawy, 2002.) This may be due to the action of alpha galactosidase, which cleaves galactose stachyose. In another study Alajaji \& El-Adawy (2006) had shown that boiling of chick pea reduced stachyose up to $50 \%$ which are higher than present work (31\%). It was proved that when soaking is applied in combination with cooking, $96 \%$ reduction might occur.

\subsection{Effect of processing on the Raffinose contents}

Raffinose contents of different chickpea varieties are shown in Table 3, ranging between $0.81 \pm 0.02$ (Dasht) to $0.63 \pm 0.05$ (Karak3). Raffinose varied significantly $(\mathrm{P}<0.05)$ among 
Table 2. Effect of different processing methods on stachyose (\%) of chickpea.

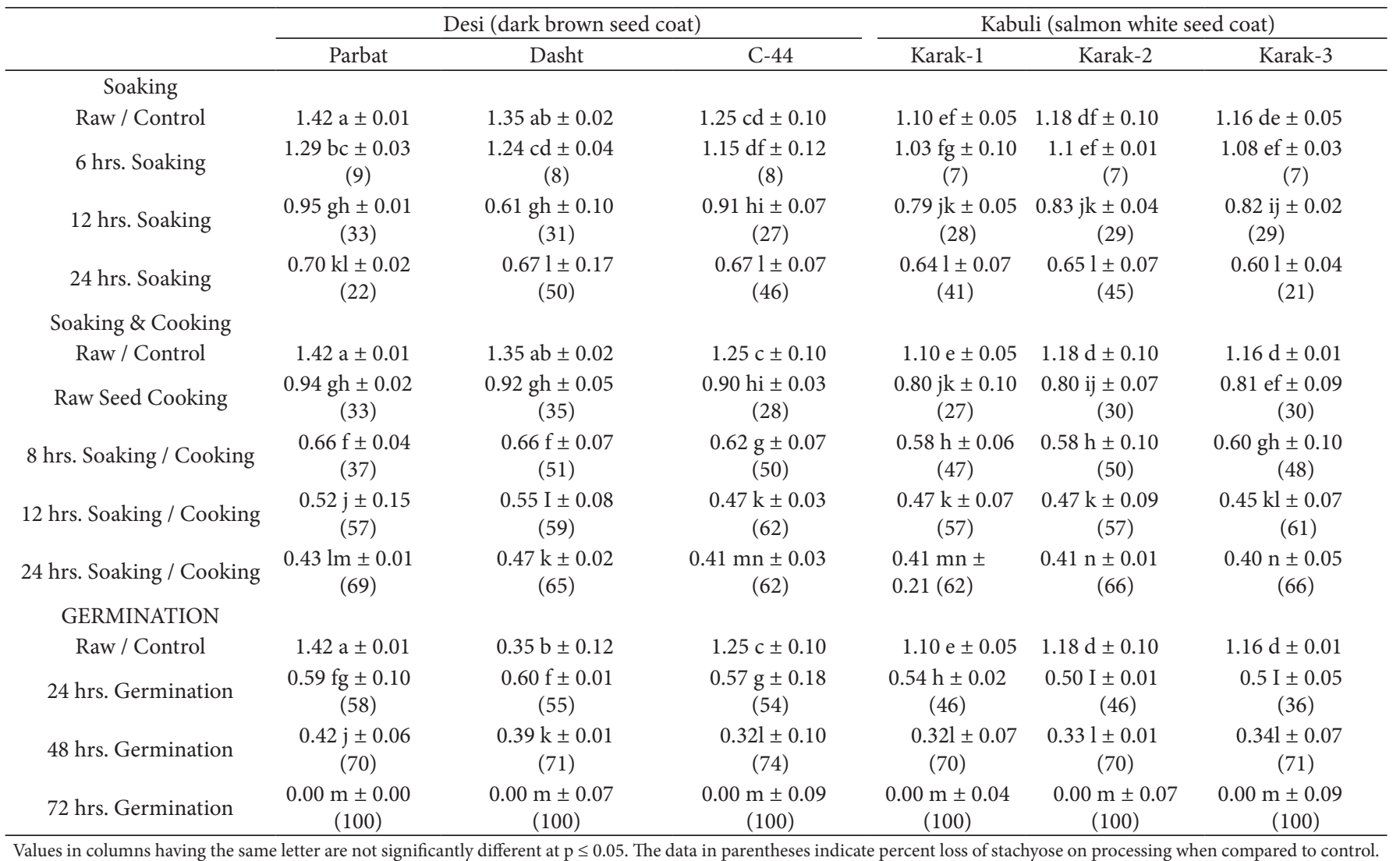

Table 3. Effect of different processing techniques on raffinose (\%) of chickpea.

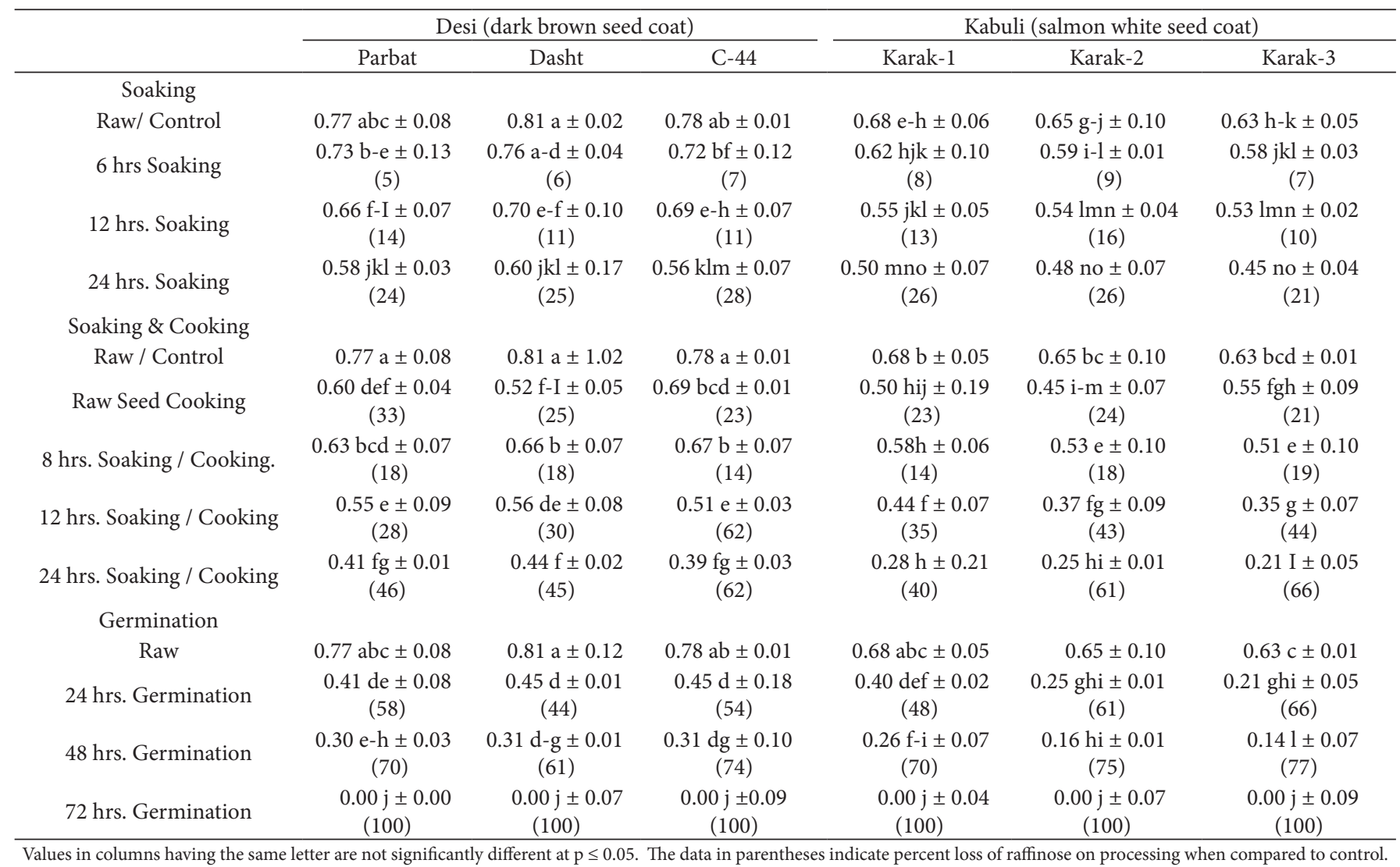


different varieties. It decreased with increasing hours of soaking and up to 24-28\% loss was observed after 24 hours. Cooking treatment also play vital role in raffinose reduction (16\%) and when soaking ( 24 hours) and cooking are combined then loss of raffinose extended to $66 \%$ in Karak 3. Germination process completely removed raffinose contents after 72 hours. These results are in close agreement with Jood et al. (1987) who reported that raffinose contents of advance lines of chickpea ranged between 0.64 to $0.85 \%$. Results are also similar to Alajaji \& El-Adawy (2006) in which boiling of chick pea reduced raffinose up to $69 \%$. The results are slightly different from Chau et al. (1998) who reported 10-15\% loss of raffinose in three Chinese indigenous cowpea seeds that might be due to crop difference. Results also support the finding of El-Adawy (2002), who found that more than $80 \%$ raffinose loss after 48 hours of germination.

\section{Conclusion}

Chick pea is reportedly rich source of protein however, due to presences of antinutritional factors and phenols many physiological disorders are associated with this group of legumes. As shown in the present study Dasi and Kabuli chickpea varieties are significantly $(\mathrm{p}<0.05)$ different for these factors. The harm fully effects of compounds can be reduced by applying simple house hold cooking and processing methods. Tannic acid reduced up to $50 \%$ by cooking of germinated seeds while raffinose and stachyose are completely removed by germination process and considered as most effective method to reduce the antinutritional factors of chickpea.

\section{References}

Afsana, K. K., Shiga, K., Ishizuka, S., \& Hara, H. (2004). Reducing effect of ingesting tannic acid on the absorption of iron, but not of zinc, copper and manganese by rats. Bioscience, Biotechnology, and Biochemistry, 68(3), 584-592. PMid:15056891. http://dx.doi. org/10.1271/bbb.68.584.

Ahmed, M. B., Rashed, A. H., Ali, M. E., Hasan, A. B., \& Babiker, E. E. (2006). Proximate composition, antinutritional factors and protein fractions of guar Gum seeds as influenced by processing treatments. Pakistan Journal of Nutrition, 5(5), 481-484. http:// dx.doi.org/10.3923/pjn.2006.481.484.

Alajaji, S. A., El-Adawy, T. A. (2006). Nutritional composition of chickpea (Cicer arietinum L.) as affected by microwave cooking and other traditional cooking methods. Journal of Food Composition and Analysis, 19, 806-812.

American Association of Cereal Chemist - AACC. (2000). Approved methods of American Association of Cereal Chemist. Minnesota: AACC.

Association of Official Analytical Chemists - AOAC. (2005). Official methods of analysis of the Association of Official Analytical Chemists (18th ed.). Washington: AOAC.

Brummer, Y., Kaviani, M., \& Tosh, S. M. (2015). Structural and functional characteristics of dietary fibre in beans, lentils, peas and chickpeas. Food Research International, 67, 117-125. http://dx.doi.org/10.1016/j. foodres.2014.11.009.

Chau, C. F., Cheung, P. C., \& Wong, Y. S. (1998). Effect of cooking on content of amino acid and antinutritients of three Chinese indigenous legume seeds. Journal of the Science of Food and
Agriculture, 75(4), 447-452. http://dx.doi.org/10.1002/(SICI)10970010(199712)75:4<447::AID-JSFA896>3.0.CO;2-5.

Dubois, M., Gilles, K. A., Hamilton, J. K., Rebers, P. A., \& Smith, F. (1956). Colorimetric method for determination of sugars and related substances. Analytical Chemistry, 28(3), 350-356. http://dx.doi. org/10.1021/ac60111a017.

El-Adawy, T.A. (2002). Nutritional composition and antinutritional factors of chickpea (Cicer arietinum L.) undergoing different cooking methods and germination. Plant Foods for Human Nutrition (Dordrecht, Netherlands), 7, 83-97.

Esenwah, C. N., \& Ikenebomeh, M. J. (2008). Processing effects on the nutritional and anti-nutritional contents of African Locust Bean (Parkia biglobosa Benth.). Seed Pak J Nutr, 7(2), 214-217. http:// dx.doi.org/10.3923/pjn.2008.214.217.

Hameed, T., Sagar, M. A., Naseem, K., \& Malik, B. A. (1999). Effect of processing methods on the tannin content of lentil and chickpea. Journal Science, Technology and Development, 18, 33-35.

Jood, S., Chauhan, B. M., \& Kapoor, A. C. (1987). Polyphenols of chickpea and blackgram as affected by domestic processing and cooking methods. Journal of the Science of Food and Agriculture, 39(2), 145-149. http://dx.doi.org/10.1002/jsfa.2740390207.

Khokhar, S., \& Chauhan, B. M. (1986). Antinutritional factors in Moth Bean (Vigna aconitifolia): varietal differences and effects of methods of domestic processing and cooking. Journal of Food Science, 51(3), 591-595. http://dx.doi.org/10.1111/j.1365-2621.1986.tb13887.x.

Lukow, O. M., \& Bushak, W. (1984). Influence of germination on wheat quality, (bread making) and biochemical properties. J Cereal Chem, 61, 336-339.

Masud, T., Talat, M., Asia, L., Shehla, S., \& Tabassum, H. (2007). Influence of processing and cooking methodologies for reduction of phytic acid content in wheat (triticum aestivum) varieties. Journal of Food Processing and Preservation, 31(5), 583-594. http://dx.doi. org/10.1111/j.1745-4549.2007.00147.x.

Moussou, N., Corzo-Martínez, M., Sanz, M. L., Zaidi, F., Montilla, A., \& Villamiel, M. (2017). Assessment of Maillard reaction evolution, prebiotic carbohydrates, antioxidant activity and $\alpha$-amylase inhibition in pulse flours. Journal of Food Science and Technology, 54(4), 890900. PMid:28303040. http://dx.doi.org/10.1007/s13197-016-2298-5.

Mubarak, A. E. (2005). Nutritional composition and antinutritional factors of mung bean seeds (Phaseolus aureus) as a affected by some home traditional processes. Food Chemistry, 89(4), 489-495. http:// dx.doi.org/10.1016/j.foodchem.2004.01.007.

Myhara, R. M., Nilsson, K., Skura, B. J., Bowmer, E. J., \& Cruickshank, P. K. (1988). Gas production from melibiose, raffinose and white bean extracts by bacteria of human fecal origin. Canadian Food Sci Technol J, 21(3), 245-250. http://dx.doi.org/10.1016/S0315-5463(88)70812-3.

Osman, M. A. (2007). Effect of different processing methods, on nutrient composition, antinutrional factors, and in vitro protein digestibility of Dolichos Lablab Bean [Lablab purpuresus (L) Sweet]. Pakistan Journal of Nutrition, 6, 299-303. http://dx.doi.org/10.3923/ pjn.2007.299.303.

Prasad, K. S., \& Singh, M. K. (2015). Horse gram-an underutilized nutraceutical pulse crop: a review. Journal of Food Science and Technology, 52(5), 2489-2499. PMid:25892749. http://dx.doi. org/10.1007/s13197-014-1312-z.

Ramakrishna, V., Rani, P. J., Rao, P. R. (2006). Anti-nutritional factors during germination in Indian Bean (Dolichos lablab L.) seeds. World Journal of Dairy \& Food Sciences, 1, 6-11.

Rao, U., \& Deosthale, Y. G. (1982). Tannin content of pulses varietals differences and effects of germination and cooking. Journal of the 
Science of Food and Agriculture, 33(10), 1013-1016. http://dx.doi. org/10.1002/jsfa.2740331012.

Singh, N., \& Kayastha, A. M. (2013). A novel application of Cicer a-galactosidase in reduction of raffinose family oligosaccharides in soybean flour. Journal of Plant Biochemistry and Biotechnology, 22(3), 353-356. http://dx.doi.org/10.1007/s13562-012-0173-7.

Singh, U., Subrahmanyam, N., \& Kumar, J. (1991). Cooking quality and nutritional attributes of some newly developed cultivars of chickpea
(Cicer arietinum). Journal of the Science of Food and Agriculture, 55(1), 37-46. http://dx.doi.org/10.1002/jsfa.2740550106.

Steel, R., Torrie, J., \& Dickey, D. (1996). Principles and procedures of statistics: a biometrical approach (3rd ed.). New York: McGraw Hill.

Tahir, M., Båga, M., Vandenberg, A., \& Chibbar, R. N. (2012). An assessment of Raffinose Family Oligosaccharides and sucrose concentration in Genus. Crop Science, 52(4), 1713-1720. http:// dx.doi.org/10.2135/cropsci2011.08.0447. 